\title{
The Influence of Values and the Social Environment on the Environmental Attitudes of Students: The Case of Lithuania
}

\author{
Rūtenis Jančius ${ }^{1, *}$, Algirdas Gavenauskas ${ }^{1}$ and Antanas Ūsas ${ }^{2}$ \\ 1 Institute of Environment and Ecology, Faculty of Forestry and Ecology, Agricultural Academy, Vytautas \\ Magnus University, 44248 Kaunas, Lithuania; algirdas.gavenauskas@vdu.lt \\ 2 Department of Sports and Tourism, Faculty of Sport and Tourism Management, Lithuanian Sports University, \\ 44221 Kaunas, Lithuania; antanas.usas@lsu.lt \\ * Correspondence: rutenis.jancius@vdu.lt
}

Citation: Jančius, R.; Gavenauskas, A.; Ūsas, A. The Influence of Values and the Social Environment on the Environmental Attitudes of Students: The Case of Lithuania. Sustainability 2021, 13, 11436. https://doi.org/ $10.3390 /$ su132011436

Academic Editor: Marco Lauteri

Received: 12 September 2021

Accepted: 13 October 2021

Published: 16 October 2021

Publisher's Note: MDPI stays neutral with regard to jurisdictional claims in published maps and institutional affiliations.

Copyright: (c) 2021 by the authors. Licensee MDPI, Basel, Switzerland. This article is an open access article distributed under the terms and conditions of the Creative Commons Attribution (CC BY) license (https:// creativecommons.org/licenses/by/ $4.0 /)$.

\begin{abstract}
The aim of this study was to analyze the influence of values and social environmental factors on the pro-environmental attitudes of students. A representative survey of 1161 Lithuanian schoolchildren was conducted between October and November 2020. Health was the most important value for students, and for girls, while healthcare was more important for boys. Among the ecological values, unpolluted food, clean air, and fresh water were the most important. For Lithuanian students, school does not play a decisive role in outdoor behavior compared to family, which plays a more important role in outdoor behavior, and friends are the most important influencers of outdoor behavior. Students in Lithuania have a pro-ecological outlook, which is shaped by their interest in and practice of ecology. Students of ECO schools are more responsible than students of regular schools, although they have less pro-environmental attitudes compared to students of regular schools.
\end{abstract}

Keywords: values; social environment; New Ecological Paradigm; education; ecological approach; Lithuania

\section{Introduction}

During the occupation period, the aim of environmental education in Lithuania was to provide students with the knowledge to identify natural resources and how to use them for the needs of the national economy, as well as to fight diseases in agricultural crops using chemical means to increase yields. "The Bolshevik reform of science teaching has created the conditions for the formation of a society indifferent to the protection of the natural environment" [1] (pp. 88-89).

When Lithuania regained its independence, it was necessary to fundamentally revise the education system in order to support the formation of values in young people, which is one of the foundations of a proper human relationship with the natural environment. In order to educate and shape the ecological approach of a young person, one of the objectives of the Law on Education of the Republic of Lithuania [2] is to develop value orientations in a person, making them honest, knowledge-seeking, independent, responsible, and patriotic, with social competences and the abilities to independently create their own life path and maintain a healthy lifestyle (Art. 3, p. 1, [2]). The Law on Education also seeks to empower society by ensuring the sustainable development of the national economy, environment, and human resources (2021, Art. 3, p. 3,4, [2]). In order to achieve these goals, the legislator stipulated that the content of education should be designed in accordance with the needs of the Lithuanian society, as determined by the changing sociocultural environment, the needs of the local and school community, and the experience, educational needs, and interests of students (2021, Art. 4, p. 2, [2]).

The Lithuanian general education curricula prescribe that a student should be educated as an integral individual with spiritual, intellectual, and physical maturity, who has the capacity for experience and the construction of meaning, as well as attitudes that 
encompass the knowledge, understanding, abilities, and responsibility for their actions and choices. The curricula also require that students develop moral, social, cultural, civic, and national awareness and a set of competences that enable them to contribute to the sustainable development of an advanced economy.

In basic education (grades 5-10), the aim is to develop the attitudes of students to take responsibility for their actions and decisions in a personal, social, civic, and cultural context, and to behave in a safe, healthy, and positive manner. In secondary school, attitudes are developed that enable students to take initiatives to create, be active, make positive changes in their environment, and take responsibility for a safe and healthy lifestyle.

The Lithuanian education system has adopted the Integrated Program for Sustainable Development [3], which states that during basic education, students develop the skills to understand the patterns and expressions of the sustainable development of society at the individual, communal, national, and global levels. At this education level, they should acquire the knowledge and skills needed to make and implement positive decisions toward sustainable development, one aspect of which is to achieve a better quality of life. In secondary school (grades 11-12), students are encouraged to reflect on the diversity and universal values of the national and global cultural heritage and to develop the ability to communicate and cooperate, solve problems, and relate to people through mutual understanding. The content of the Integrated Program for Sustainable Development is based on a societal development approach, emphasizing the interdependence of the natural environment, culture, social and economic life of society, future-oriented creative thinking, and creation of a quality life for oneself and for future generations [3].

In both primary and secondary education, the curricula aim to help students understand the world in which they live, the systems and processes that sustain life on the planet, and the responsible application of natural science in their daily lives and careers. Students are taught scientific concepts, general and specific subject-specific skills, values that are not alien to general human morality, personal responsibility, and participation in sustainable development issues to the best of their competence and ability.

These documents, both at the national level and at the individual pupil level, aim to develop appropriate attitudes and behaviors that protect the natural environment in which they live and work. It is understood that the aim is for young people to behave in a socially responsible way, which would mean social responsibility with individual and social goals.

"Attitudes make the greatest impact on human behavior only when there are favorable conditions. That is, being influenced by attitudes, certain behavior may sometimes not be performed due to individual characteristics of a person". ([4], p. 75)

The aim of this study was to analyze the influence of values and social environmental factors on the pro-environmental attitudes of students. The New Ecological Paradigm (NEP) scale was used to assess the environmental attitudes of respondents. The authors identified the following research questions:

(1) Do the personal and ecological values of students influence the formation of ecological attitudes?

(2) Does the social environment influence the formation of attitudes toward the natural environment?

(3) Does an interest in and practice of ecology influence ecological attitudes?

The authors of the study conducted a single analysis, so causality is not examined. In order to achieve the goal, this article sets the following objectives: To analyze the concept of values and the meaning of ecological attitudes; to analyze the meaning of ecological ethics; to analyze the meaning of the social environment for the formation of ecological attitudes; to analyze the role of education in the formation of ecological attitudes of students. 


\section{Literature Review}

\subsection{The Concept and Meaning of Values}

Mankind has become desensitized to nature, leading to major environmental problems. Humanity must find solutions to ensure environmental sustainability and natural resources for future generations [5]. The natural environment sustains human well-being in many different and complex ways, providing both tangible and intangible benefits. Effective conservation of ecosystems requires a context-specific understanding of human interactions with nature [6].

Targamadzè [7] identified values as the everyday guide of human life, the alpha and omega of our lives, which form the foundation of human life. Human actions are understood in terms of norms derived from values, because the natural structure of actions does not in itself tell us anything about their moral value. Values are manifested as a specific, goal-oriented attitude of consciousness, awareness of ideas and images, and following them [8]. Values are a distinguishing characteristic of human beings that influence the choice between possible courses of action, means, and ends [9]. According to Shams [10], values are deep-rooted beliefs that influence goals, decisions, and behavior, as well as being the basis for attitudes, motives, behaviors, and the underlying assumptions on which society exists. The importance of human values in life underlines the integral role they play in improving the quality of life, which also determines human actions and behavior in everyday situations [11]. Huguelet [12] proposed to define values as implicit or explicit principles that are oriented toward personal action. They are seen as reinforcing factors whose benefits are often delayed, but which promote a sense of meaning.

Jones [13] noted that " ... values can complement the use of other forms of cognition ..." to better understand how people emotionally interact with natural systems. Environmental values are the beliefs a person or society has about the meaning, " ... importance and well-being of the natural environment and how it should be viewed and treated" (pp. 1-2, [13]). Liobikiene [14] stated that values help to shape decisions people make about the world around them and organize the basic principles and attitudinal determinants of life.

Values are the basic priorities, interests, beliefs, and attitudes of a society, a group, or an individual that define the principles by which a person should behave [15]. Values influence attitudes toward the environment, perceptions of the consequences of behavior, and acceptance of responsibility, and contribute to environmentally friendly behavior [16]. Jančius [17] observed that values encompass human behavior for the sake of well-being by encouraging reflection on and cultivation of other values and behaviors, and become more effective in building the well-being of oneself and others. Kociszewska [18] identified the domains of cognitive-ecological perception, i.e., knowledge of the processes taking place in nature, of existing risks, of human activities and their negative consequences; a system of values, which are fulfilled by interacting with nature and which encompass life, health, responsibility, work, beauty, harmony, and others; and a domain of rules for action. Environmental knowledge, values, and attitudes toward the environment are the most commonly cited components of environmental awareness, which are considered to be interactive, and environmental knowledge can lead to increased concern and awareness, which in turn can lead to changes in behavior [19].

Omoogun [19] identified knowledge as a means of helping social groups and individuals to acquire a range of experiences, understanding of the environment and its problems; attitude as a means of helping them to acquire values and concern for the environment, and to have the motivation to take an active part in improving and protecting the environment; and skills as a means of helping them to develop the ability to identify and solve environmental problems. Through the conceptual knowledge and skills acquired through environmental education, people also acquire the awareness that " ... enables them to act $\ldots$, and the values and attitudes that motivate and empower individuals and groups to work, and promote the sustainability ... " in dealing with current and future environmental problems (p. 64, [20]). Human attitudes toward the natural environment, information 
and beliefs about the environment, and value systems about the environment determine human behavior [21]. In light of the theoretical considerations in this study, we formulated a hypothesis examining the influence of the values of students on their attitudes.

Hypothesis 1 (H1). The values of students influence their attitudes toward the natural environment.

\subsection{The Significance of the Social Environment}

People create the environment from which they learn and where they receive the negative elements that shape the behavior of young people. Negative behavior is the result of immature thinking and lack of life experience. Social environmental factors can influence and be a source of learning in shaping behavior through various social learning models [22]. Social maturity is the ability to achieve an acceptable level of social behavior. Students should be exposed to socially mature people so that they can model their behavior accordingly [23].

Attitudes and motivation are transmitted from the social environment to the child when they are growing up and are essential sources of motivation and attitude formation. The social environment comprises different levels of influence on the child: The most influential are the family and peers, the school, neighbors, the media, and the parental workplace. The child is influenced by society, culture, history, economics, and national laws [24]. Thomas [25] observed that, within the family, mothers are more concerned about the health and safety of their children, while fathers are generally more concerned about the material well-being of the family and less concerned about the environment. The family environment influences the performance of students and inspires parents to develop appropriate attitudes toward school and education, cultural baggage, and a value system [26]. The family environment plays an important role in the well-being and social development of adolescents [27].

The classroom social environment focuses on the learning and competences of students and includes a range of effective teaching strategies that challenge and motivate students. Stewart [28] indicated that the school environment, in addition to the professional experience of teachers, influences the teaching of philosophy and attitudes toward learning, which can affect the perception of students about the social environment of the classroom. This environment enhances the motivation, well-being, and adjustment of adolescents at school by developing their academic and social competences. School is a privileged place for promoting well-being, where adolescents can be happy and healthy by making friends, developing social and emotional skills, and developing their personality [29]. Garibaldi [30] saw schools as emotional systems that develop social, emotional, and academic skills in children and young people that help them make friends, resolve conflicts respectfully, and make ethical choices. The following hypothesis was developed on the basis of the above considerations:

Hypothesis 2 (H2). The social environment of students influences their attitudes toward the natural environment.

\subsection{Ecological Approach to Nature}

The guiding principles of environmental issues are behavioral principles [31]. Teaching must be based on the knowledge and attitudes of students toward environmental protection. The diversity of traditions, religious and spiritual attitudes, and philosophies can lead to different views of nature and the environment. By understanding the relationship between human attitudes toward the environment and the factors that influence these attitudes, it is possible to find the right way of teaching to improve societal attitudes toward nature [32].

Tarfaoui [33] noted that attitudes tend to evaluate an object favorably or unfavorably and can also define and guide action and dictate behavior. Marcinkowski [34] indicated that attitudes have cognitive, affective, and behavioral components such as dispositions that can influence behavior. Predicting a specific behavior requires a specific attitude toward 
that behavior. When the specificity of attitude and behavior is high, attitude is more likely to predict behavior and the relationship between the two becomes stronger. Environmental behavior is different from environmental attitudes, and attitudes alone do not guarantee environmental behavior [33]. Attitudes predict or influence behavior, which depends on many factors (beliefs, the nature and strength of emotions, etc.). Marcinkowski [34] defined environmental behavior as the attitude of an actor, as a behavior that aims to change the environment and an intention that becomes an independent cause of the behavior but may have no effect on the environment. An intention is both a personal factor, whereby a person favours or disfavours a particular behaviour, and a social factor, whereby there is perceived social pressure to perform or not to perform the behaviour [35]. Leeuw [36] notes that negative behavior is the result of immature thinking and lack of life experience. Young people bear the burden of past and present environmental neglect, which is also a driver of behavior change.

Attitudes have three components: The cognitive attitude, which consists of individual beliefs or opinions; the conative attitude, which expresses the emotional aspect; and the affective attitude, which manifests itself through human behavior [37,38]. Attitudes as a combination of beliefs, emotions, and behavior toward the environment, based on knowledge and information on environmental issues, create positive attitudes toward the environment and environmental education [39]. Behaviours are beliefs that influence attitudes towards behaviour, and normative beliefs, which are the main determinants of subjective norms. Each behavioural belief links a behaviour to a particular outcome or to some other attribute, such as the costs incurred in performing the behaviour. " ... Subjective value then contributes to the attitude toward the behavior in direct proportion to the strength of the belief, i.e., the subjective probability that performing the behavior will lead to the outcome under consideration" (p. 455, [35]). Lucarelli defines pro-environmental behaviour as behaviour that consciously seeks to reduce the "negative impacts of the one's actions on the on natural and the built world [40]."

Human behavior has led to environmental problems, which are moral problems that require ethics and morality to overcome. The ecocrisis that humanity is experiencing is the result of fundamental philosophical errors in thinking about ourselves, nature, and the ecosystem as a whole. Misperceptions can lead to mistreatment of nature. Preventing a more severe crisis requires appropriate human attitudes and behavior in our relationship with nature and with other people throughout the ecosystem [41]. To reduce environmental degradation, we need to educate the public about environmental issues by providing knowledge, skills, values, environmental attitudes, and solutions to environmental problems [42].

The beliefs, values, and attitudes of a person influence their behavior. Attitude is defined as an evaluation "... based on cognitive, emotional, and behavioral information and is a combination of cognition, feelings, and readiness to do something" (p. 145, [43]). In order to change their behavior, people must first change their attitudes [43], which are shaped by their emotions, opinions, and behavior toward an object. Saricam [44] indicated that if a person has a positive attitude toward an object, they will tend to behave positively, i.e., the person will show concern for the object and help it. Attitudes toward the environment are also shaped by all of the positive or negative opinions a person has about the environment and their behavior toward it. A stronger emotional response from a person can lead to favorable environmental behavior. Emotional connection is important in shaping beliefs, values, and attitudes toward the environment [45]. Therefore, the hypothesis presented in this study examines the influence of interest in and practice of ecology on attitudes toward the relationship between humans and the environment.

Hypothesis 3 (H3). Interest in and practice of ecology influences ecological attitudes. 


\subsection{The Significance of Education}

Environmental education involves the transmission of environmental knowledge and cognitive and emotional values that encourage people to change their attitudes toward the environment and to foster good environmental behavior [46]. Education for sustainable development enables everyone to acquire the knowledge, values, and skills needed to make individual or collective decisions to improve the quality of life now, without compromising the needs of future generations [47].

Education is considered necessary in the context of environmental issues [48] to improve the human capacity to deal with environmental and developmental problems that are intrinsically linked to sustainable development [49]. Environmental education develops knowledge, attitudes, and skills related to the environment by providing the foundations for a sustainable environment. Acquiring and possessing environmental knowledge refers to knowledge and understanding of environmental problems and possible solutions [50]. Effective environmental education strengthens environmental attitudes, values, and knowledge, and develops skills that encourage people to take positive environmental action [51].

Environmental education contributes to more sustainable human attitudes and behavior, but knowledge is less important in predicting behavior than emotional connection to nature and environmental beliefs, which are more related to acting in favor of the environment [52]. Education about environmental issues would encourage awareness, concern for the environment, and environmentally friendly behaviour. "However, awareness and understanding alone cannot make it successful unless behavioral mechanisms steer individuals to accept their responsibility towards the environmental" (p. 1, [40]). If environmental awareness is not developed, it cannot change environmental attitudes, which will continue to lead to man-made environmental problems and have a negative impact on the world. Thor [53] stated that environmental awareness and lifelong learning encompasses all levels of education so that people have a clear understanding of the economic, social, politi$\mathrm{cal}$, and ecological interconnections. Everyone should have opportunities to acquire the knowledge, values, attitudes, responsibilities, and skills they need to protect and improve the environment. Educational institutions are the vehicle for environmental education in modern society, providing the knowledge, skills, and behavior appropriate to address environmental issues, and the behavior, attitude, and ecological commitment of the leader can influence the environmental knowledge and perception of harmful behaviors of young people $[54,55]$. The aim of environmental education, whether formal or informal, is to raise awareness, empowering people to take and implement solutions to solve the environmental crisis and improve their quality of life without harming the planet. Achieving this goal requires environmental awareness and understanding, integrating the intrinsic values of sustainable development, which should be deeply rooted in all levels of the education system, involving interest, feelings, knowledge, skills, attitudes, and cooperation [56-58].

For students, the role of education is to develop positive attitudes, duty, and responsibility toward the environment. Students learn about nature and develop a better attitude toward the environment in which they live [59]. Lamanauskas [46] stated that the main function of attitude is to help a person to orient himself meaningfully in his social environment, which is formed depending on age, value attitudes, cognitive period, and social experience. Based on previous studies, the following hypothesis was developed.

Hypothesis 4 (H4). Eco-school students take more responsibility for the natural environment.

Ecological attitudes can be measured (Figure 1) through the values of the student, the social environmental factors (family, friends, etc.), the extent to which the student is interested in ecology and tries to apply this knowledge in their life, and the contribution of the school in shaping the ecological attitude of the student, which leads to a responsible way of life. 


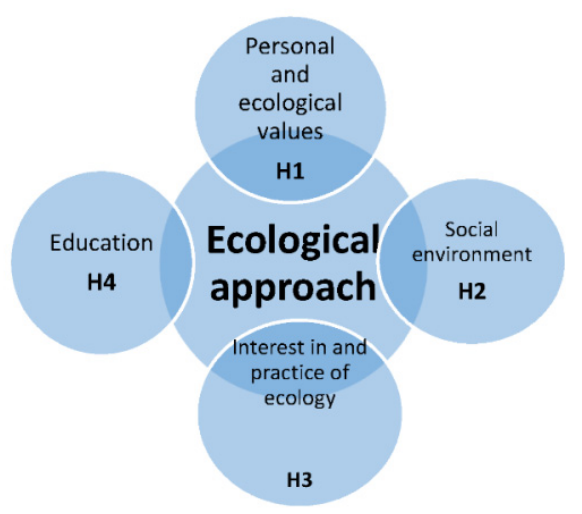

Figure 1. Assessment of the ecological approach (source: Created by the authors).

\section{Materials and Methods}

\subsection{Survey Respondents}

For the purpose of this study, schools that educate students on the basis of the concept of ecology and environmental technology education approved by the Minister of Education and Science of the Republic of Lithuania on 16 July 2015 [60] were contacted. Scientists from Vytautas Magnus University, the Academy of Agriculture, and the Faculty of Forestry and Ecology participated in the preparation of the document as consultants. The main objective of the concept was "to develop a mature personality with fundamental knowledge, skills, and values in ecology and environmental technologies, capable of making independent choices about appropriate behavioral strategies, of anticipating the environmental consequences of their actions, and of taking an active role in preserving the environment" (Article 6, [60]). Schools that are part of the ECO Schools Network (established in 2016), which strive for harmony with the surrounding environment, fostering eco-friendly ideas, and developing the community's eco-competences were also approached. This research also involved mainstream basic and secondary (gymnasium) education schools, whose educational principles were presented in the introduction to the study.

A representative survey of 1161 Lithuanian schoolchildren was conducted between October and November 2020 to investigate the impact of values and social environmental factors on their environmental attitudes. In order to improve the survey instrument, a pilot survey was first conducted in one of the schools. Respondents were selected by the curriculum. The sample size included a sampling error of 5\% at a significance level of $95 \%$. The demographic characteristics of the study are shown in Table 1.

This study involved 1161 respondents of different genders, ages, and curricula: $46.3 \%$ male and $53.7 \%$ female. The age distribution was as follows: $21.9 \%$ were in the $11-14$ year age group, $40.0 \%$ were in the $15-16$ year age group, and $38.2 \%$ were in the $17-18$ year age group. Of the students, $21.9 \%$ were in grades $5-8,40.0 \%$ in gymnasium grades I-II, and $38.1 \%$ in gymnasium grades III-IV. The distribution of students by curriculum was as follows: Non-traditional education accounted for $32.6 \%$ of the respondents, while $67.4 \%$ of the students were enrolled in general education programs. 
Table 1. Demographic characteristics of the survey participants.

\begin{tabular}{ccc}
\hline & Number (N) & Percentage \\
\hline Gender & 537 & \\
\hline Male & 624 & 46.3 \\
\hline Female & & 53.7 \\
\hline Place of residence & 642 & 55.3 \\
\hline City & 266 & 22.9 \\
\hline Town & 253 & 21.8 \\
\hline Village & & \\
\hline Grade & 74 & 6.4 \\
\hline 5th grade & 66 & 5.7 \\
\hline 6th grade & 62 & 5.3 \\
\hline 7th grade & 52 & 4.5 \\
\hline 8th grade & 320 & 27.6 \\
\hline Gymnasium grade I & 144 & 12.4 \\
\hline Gymnasium grade II & 223 & 19.2 \\
\hline Gymnasium grade III & 220 & 18.9 \\
\hline Gymnasium grade IV & 379 & \\
\hline By school type & & 67.4 \\
\hline Non-traditional education & & \\
\hline General education & & \\
\hline
\end{tabular}

\subsection{Empirical Study Measurements}

Likert scales were used in the questionnaires to obtain the degree to which a respondent agrees with a statement or set of statements [61]. The questionnaire instrument for this study measured the personal values of the respondents using a Likert scale ranging from very important (6) to very unimportant (1). The ecological values of the students were measured from very important (5) to very unimportant (1), constructed on the basis of Kalenda's [62] ecological values distinction, which analyzes the relationship with the natural environment as a basis for existence. The construct, which analyzes the factors influencing the behavior of respondents in nature, is measured on a Likert scale, i.e., the factor is a strong determinant of behavior (1) or a weak determinant (5). In order to assess the ecological attitudes of the students toward the environment, the New Ecological Paradigm (NEP) instrument [63] was used, which scales the environmental attitudes and the proenvironmental worldview of people [64], as well as measures the general orientation toward nature and the relationship between people and the environment $[65,66]$.

To investigate the relationship between one dependent variable and one independent variable, we used linear regression analysis, where the dependent variable has a direct relationship with the independent variable.

A hypothesis is a quantitative statement formulated about the population value of a test statistic that reflects the sample of data and the sampling distribution representing the population being compared to evaluate the null hypothesis formulated. The comparison produces a $p$-value that quantifies the typicality or otherwise of the configuration and assumes that the null hypothesis is true. It is important to understand that $p$-values are obtained by comparing theoretical assumptions (sampling distribution) with real observations (data sample), assuming that $\mathrm{H} 0$ is true [67]. The $p$-value is the probability that the result will be as extreme as the null hypothesis, so when testing the hypothesis, the $p$-value is reported as $p<0.05$ to assess the level of statistical significance [68]. 


\subsection{Data Analysis}

Cronbach's alpha is a statistic used to indicate the appropriateness of survey instruments developed or adapted for research projects [69]. To assess the internal consistency of the scale, the authors of the study calculated the Cronbach's alpha coefficient $(\alpha)$, (ranging from 0 to 1 ), which evaluates the reliability and mean correlation of a one-dimensional structure. "The minimum acceptable alpha value is 0.70 , and for lower values, the internal consistency of the scale is generally considered low" (p. 4, [70]). The results showed that the Cronbach's alpha values were greater than 0.7 (Table 2), reflecting the reliability of data collection in the surveys. The collected data were statistically processed using SPSS (Statistical Package for Social Sciences) software version 26 (IBM Corp. Armonk, NY, USA).

Table 2. Questionnaire variables, questions, response categories, and internal reliability.

\begin{tabular}{|c|c|c|c|}
\hline Variables & Questions & Response Category & Cronbach's Alpha \\
\hline Personal values & $\begin{array}{l}\text { Justice } \\
\text { Work } \\
\text { Love } \\
\text { Money } \\
\text { Health } \\
\text { Peace }\end{array}$ & $\begin{array}{l}6 \text { very important } \\
1 \text { very unimportant }\end{array}$ & 0.738 \\
\hline Ecological values & $\begin{array}{c}\text { Fresh air } \\
\text { Freshwater } \\
\text { Beautiful landscape } \\
\text { Lush flora } \\
\text { Rich fauna } \\
\text { Unchanged climate } \\
\text { Uncontaminated food } \\
\text { Recreation in nature } \\
\text { Environmental protection }\end{array}$ & $\begin{array}{l}5 \text { very important } \\
1 \text { very unimportant }\end{array}$ & 0.897 \\
\hline $\begin{array}{l}\text { Human-Environment } \\
\text { Perspective (NEP) }\end{array}$ & & $\begin{array}{c}1 \text { completely agree } \\
5 \text { completely disagree }\end{array}$ & 0.855 \\
\hline $\begin{array}{l}\text { Factors affecting } \\
\text { behavior in nature }\end{array}$ & $\begin{array}{c}\text { Media (TV, radio, } \\
\text { newspapers, and magazines) } \\
\text { Family } \\
\text { Friends } \\
\text { School } \\
\text { Famous people } \\
\text { Religion } \\
\text { Non-governmental } \\
\text { organizations } \\
\text { Advertising }\end{array}$ & $\begin{array}{c}1 \text { strongly influences } \\
5 \text { does not influence at } \\
\text { all }\end{array}$ & 0.777 \\
\hline
\end{tabular}

\section{Results}

\subsection{Do the Personal and Ecological Values of Students Influence Their Formation of Ecological Attitudes?}

First, the values of the students were assessed and the results were obtained (Figure 2. The most important values for the respondents were health, justice, peace, and work.

The value of health was identified as the most important value by $96.30 \%$ of the respondents, while $2 \%$ of the students did not consider health to be important. Therefore, we can conclude that health is one of the most important values for Lithuanian students. The results showed that the value of money was of little importance to students, but the value of love was the least important, with only $85.01 \%$ of the respondents indicating that it was important, and almost $6 \%$ indicating that it was not important at all in their lives. When analyzing the data by gender, the value of health was more important for girls $(52.19 \%)$ than for boys $(44.10 \%)$. 


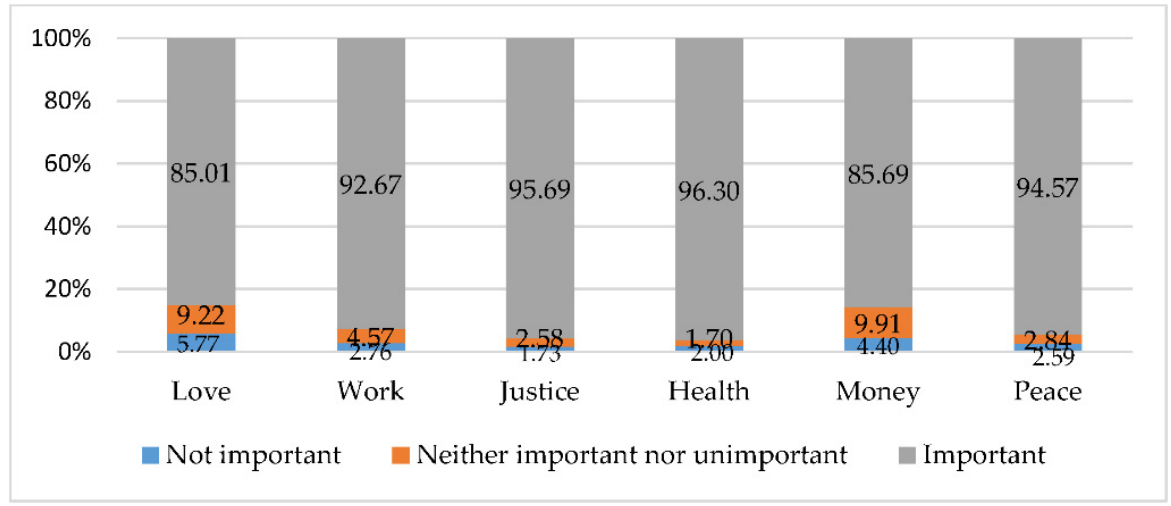

Figure 2. Human values of the students.

Using linear correlation analysis, the results showed a statistically significant linear relationship between the selected variables $(p=0.00, p<0.01)$. Justice was found to correlate with peace (0.545), work with justice (0.472), and the value of health with peace (0.537).

The analysis of the ecological values (Figure 3 ) showed some correlation with the personal values of the students, with $95.17 \%$ of the students indicating that non-contaminated food was most important to them, and only $1.47 \%$ of the students indicating that food contamination was not important to them.

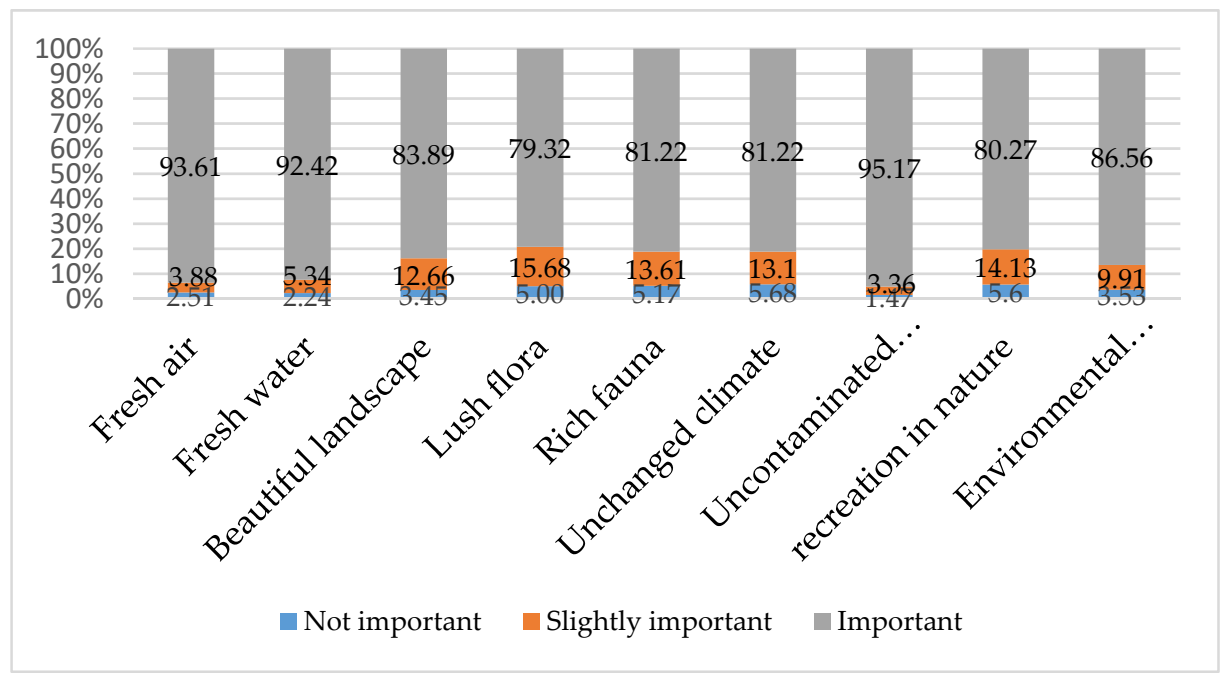

Figure 3. Ecological values of the students.

The students take care of their health and try to eat healthy food, which is also reflected in the results of the other ecological values, i.e., students care about clean $(93.61 \%)$ and fresh $(92.42 \%)$ water. The least important value for the students was lush flora, with only $79.32 \%$ of the respondents indicating it as an important value, and $5 \%$ indicating it as unimportant.

Using linear correlation analysis (Table 3), the results showed that there was a moderate correlation (0.679) between clean air and freshwater values, which means that students associate air quality with freshwater quality. 
Table 3. Correlation of the ecological values.

\begin{tabular}{|c|c|c|c|c|c|c|c|c|c|}
\hline & 1 & 2 & 3 & 4 & 5 & 6 & 7 & 8 & 9 \\
\hline Fresh air & & 0.679 ** & $0.430 * *$ & 0.483 ** & 0.481 ** & $0.482 * *$ & 0.556 ** & 0.440 ** & 0.537 ** \\
\hline Fresh water & & & $0.398^{* *}$ & 0.439 ** & $0.418^{* *}$ & $0.448^{* *}$ & $0.513 * *$ & $0.330 * *$ & $0.408^{* *}$ \\
\hline Beautiful landscape & & & & $0.628^{* *}$ & $0.598^{* *}$ & $0.461^{* *}$ & $0.433 * *$ & 0.570 ** & $0.485^{* *}$ \\
\hline Lush flora & & & & & $0.719 * *$ & $0.573^{* *}$ & $0.425^{* *}$ & $0.476^{* *}$ & $0.538^{* *}$ \\
\hline Rich fauna & & & & & & $0.596^{* *}$ & $0.425^{* *}$ & $0.483^{* *}$ & $0.535^{* *}$ \\
\hline Unchanged climate & & & & & & & $0.472 * *$ & $0.428 * *$ & $0.529 * *$ \\
\hline Uncontaminated food & & & & & & & & $0.445^{* *}$ & $0.494^{* *}$ \\
\hline Recreation in nature & & & & & & & & & $0.535^{* *}$ \\
\hline Environmental protection & & & & & & & & & \\
\hline
\end{tabular}

A statistically significant correlation (0.719) was found between lush flora and rich fauna, suggesting that students understand the importance of unpolluted nature and rich biodiversity. The students understand that biodiversity must not be destroyed or diminished and that the importance of biodiversity is determined by their family and education at school. The first hypothesis of this study states that the value attitudes of students have an impact on their attitudes toward the natural environment $(p<0.05)$. On the basis of the results obtained, hypothesis $\mathrm{H} 1$ can be confirmed.

\subsection{Does the Social Environment Influence the Formation of Attitudes toward the} Natural Environment?

The behavior of students in nature (Figure 4) is also influenced by external factors that are relevant for the formation and development of values, awareness, and attitudes.

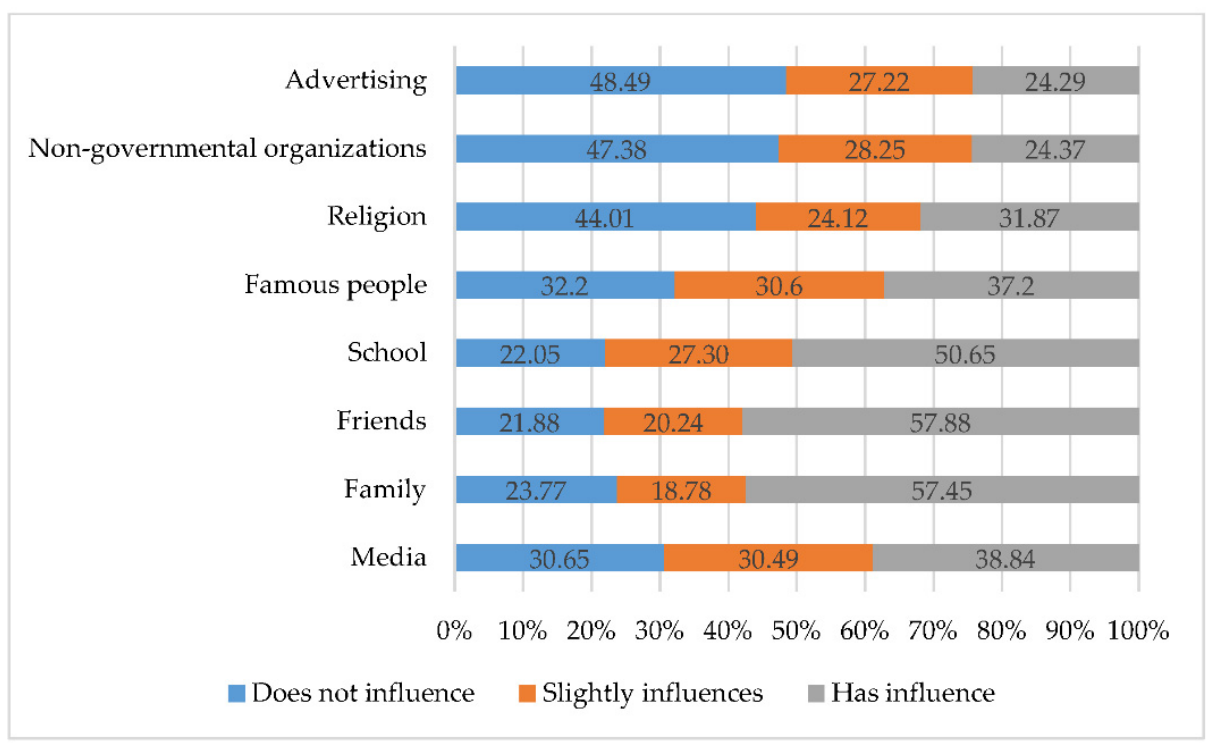

Figure 4. Social environmental factors influencing the behavior of students in the natural environment.

Students are most influenced by friends (57.88\%) and family (57.45\%). We can conclude that these factors influence not only behavior in nature, but also the formation of attitudes. It should be noted that family $(23.77 \%)$, more than friends $(21.88 \%)$, does not have any influence on outdoor behavior, as for students, these factors become determining factors due to daily interactions.

A linear correlation analysis showed statistically significant moderate relationships between school and friends (0.659), family and friends (0.650), school and family (0.542), and NGOs and advertising (0.530). Communication between families, cooperation with educational institutions, and NGOs have a decisive influence on the attitude and behavior 
of students in nature. Hypothesis $\mathrm{H} 2$ of the authors of the research that the social environment of the students influences their attitudes toward the natural environment can thus confirmed.

\subsection{NEP Dimensions}

Students tend to support pro-environmental attitudes, with the majority of respondents endorsing each statement (Table 4). The table below shows the percentage distribution of the responses.

Table 4. Agreement of the students with the NEP scale items (\%).

\begin{tabular}{|c|c|c|c|c|c|c|c|}
\hline Do you Agree or Disagree That: & $\begin{array}{c}\text { Students } \\
\text { School Type }\end{array}$ & $\begin{array}{c}\text { Completely } \\
\text { Agree }\end{array}$ & Agree & $\begin{array}{c}\text { Partially } \\
\text { Agree }\end{array}$ & Disagree & $\begin{array}{c}\text { Completely } \\
\text { Disagree }\end{array}$ & Averages \\
\hline \multicolumn{8}{|c|}{ The Reality of Limits to Growth } \\
\hline \multirow{3}{*}{$\begin{array}{l}\text { 1. We are approaching the limit of the number of } \\
\text { people Earth can support }\end{array}$} & $\mathrm{S}$ & 13.87 & 23.26 & 31.43 & 20.16 & 11.28 & 2.92 \\
\hline & 1 & 4.91 & 9.30 & 13.18 & 10.25 & 6.89 & 8.91 \\
\hline & 2 & 8.96 & 13.95 & 18.26 & 9.91 & 4.39 & 11.09 \\
\hline \multirow{3}{*}{$\begin{array}{l}\text { 6. Earth has plenty of natural resources if we just } \\
\text { learn how to develop them }\end{array}$} & $\mathrm{S}$ & 28.60 & 28.51 & 20.24 & 11.97 & 10.68 & 2.48 \\
\hline & 1 & 12.83 & 12.32 & 8.70 & 5.68 & 5.00 & 8.91 \\
\hline & 2 & 15.76 & 16.19 & 11.54 & 6.29 & 5.68 & 11.09 \\
\hline \multirow{3}{*}{$\begin{array}{l}\text { 11. Earth is like a spaceship with very limited } \\
\text { room and resources }\end{array}$} & $\mathrm{S}$ & 19.29 & 22.05 & 28.68 & 19.12 & 10.85 & 2.80 \\
\hline & 1 & 7.58 & 8.96 & 12.83 & 9.73 & 5.43 & 8.91 \\
\hline & 2 & 11.71 & 13.09 & 15.85 & 9.39 & 5.43 & 11.09 \\
\hline \multirow{2}{*}{ Averages } & 1 & 8.44 & 10.19 & 11.57 & 8.55 & 5.77 & \\
\hline & 2 & 12.14 & 14.41 & 15.22 & 8.53 & 5.17 & \\
\hline \multicolumn{8}{|c|}{ Anti-anthropocentrism } \\
\hline \multirow{3}{*}{$\begin{array}{l}\text { 2. Humans have the right to modify the natural } \\
\text { environment to suit their needs }\end{array}$} & $\mathrm{S}$ & 16.88 & 21.70 & 28.60 & 20.16 & 12.66 & 2.90 \\
\hline & 1 & 6.80 & 9.65 & 12.40 & 9.91 & 5.77 & 8.91 \\
\hline & 2 & 10.08 & 12.06 & 16.19 & 10.25 & 6.89 & 11.09 \\
\hline \multirow{3}{*}{$\begin{array}{l}\text { 7. Plants and animals have as much right to exist } \\
\text { as humans }\end{array}$} & S & 25.32 & 23.34 & 24.63 & 14.30 & 12.40 & 2.65 \\
\hline & 1 & 10.59 & 11.63 & 11.11 & 6.03 & 5.17 & 8.91 \\
\hline & 2 & 14.73 & 11.71 & 13.52 & 8.27 & 7.24 & 11.09 \\
\hline \multirow{3}{*}{$\begin{array}{l}\text { 12. Humans were meant to rule over the rest of } \\
\text { nature }\end{array}$} & $\mathrm{S}$ & 12.49 & 18.95 & 30.15 & 23.77 & 14.64 & 3.09 \\
\hline & 1 & 6.37 & 9.30 & 12.23 & 10.68 & 5.94 & 8.91 \\
\hline & 2 & 6.12 & 9.65 & 17.92 & 13.09 & 8.70 & 11.09 \\
\hline \multirow{2}{*}{ Averages } & 1 & 7.92 & 10.19 & 11.91 & 8.87 & 5.63 & \\
\hline & 2 & 10.31 & 11.14 & 15.88 & 10.54 & 7.61 & \\
\hline \multicolumn{8}{|c|}{ The Fragility of Nature's Balance } \\
\hline \multirow{3}{*}{$\begin{array}{l}\text { 3. When humans interfere with nature, it often } \\
\text { produces disastrous consequences }\end{array}$} & $S$ & 28.42 & 21.10 & 22.39 & 15.59 & 12.49 & 2.63 \\
\hline & 1 & 12.83 & 8.79 & 9.73 & 7.58 & 5.60 & 8.91 \\
\hline & 2 & 15.59 & 12.39 & 12.66 & 8.01 & 6.89 & 11.09 \\
\hline \multirow{3}{*}{$\begin{array}{l}\text { 8. The balance of nature is strong enough to cope } \\
\text { with the impacts of modern industrial nations }\end{array}$} & $\mathrm{S}$ & 12.49 & 19.55 & 24.72 & 27.22 & 16.02 & 3.15 \\
\hline & 1 & 5.68 & 8.70 & 10.16 & 12.58 & 7.41 & 8.91 \\
\hline & 2 & 6.80 & 10.85 & 14.56 & 14.64 & 8.61 & 11.09 \\
\hline \multirow{3}{*}{$\begin{array}{l}\text { 13. The balance of nature is very delicate and } \\
\text { easily upset }\end{array}$} & $S$ & 19.90 & 25.06 & 28.94 & 16.45 & 9.65 & 2.71 \\
\hline & 1 & 7.92 & 9.91 & 13.09 & 8.79 & 4.82 & 8.91 \\
\hline & 2 & 11.97 & 15.16 & 15.85 & 7.67 & 4.82 & 11.09 \\
\hline \multirow{2}{*}{ Averages } & 1 & 8.81 & 9.13 & 10.99 & 9.65 & 5.94 & \\
\hline & 2 & 11.45 & 12.8 & 14.36 & 10.11 & 6.77 & \\
\hline
\end{tabular}


Table 4. Cont.

\begin{tabular}{|c|c|c|c|c|c|c|c|}
\hline Do you Agree or Disagree That: & $\begin{array}{c}\text { Students } \\
\text { School Type }\end{array}$ & $\begin{array}{c}\text { Completely } \\
\text { Agree }\end{array}$ & Agree & $\begin{array}{c}\text { Partially } \\
\text { Agree }\end{array}$ & Disagree & $\begin{array}{c}\text { Completely } \\
\text { Disagree }\end{array}$ & Averages \\
\hline \multicolumn{8}{|c|}{ Rejection of Exemptionalism } \\
\hline \multirow{3}{*}{$\begin{array}{l}\text { 4. Human ingenuity will ensure that we do not } \\
\text { make Earth unlivable }\end{array}$} & $\mathrm{S}$ & 18.78 & 25.06 & 29.02 & 17.92 & 9.22 & 2.74 \\
\hline & 1 & 8.70 & 11.02 & 12.75 & 8.10 & 3.96 & 8.91 \\
\hline & 2 & 10.08 & 14.04 & 16.28 & 9.82 & 5.25 & 11.09 \\
\hline \multirow{3}{*}{$\begin{array}{l}\text { 9. Despite our special abilities, humans are still } \\
\text { subject to the laws of nature }\end{array}$} & $\mathrm{S}$ & 24.9 & 26.2 & 21.5 & 15.8 & 11.6 & 2.63 \\
\hline & 1 & 10.16 & 10.51 & 8.87 & 8.70 & 6.29 & 8.91 \\
\hline & 2 & 14.73 & 15.68 & 12.66 & 7.06 & 5.34 & 11.09 \\
\hline \multirow{3}{*}{$\begin{array}{l}\text { 14. Humans will eventually learn enough about } \\
\text { how nature works to be able to control it }\end{array}$} & $\mathrm{S}$ & 13.09 & 25.58 & 34.37 & 18.69 & 8.27 & 2.83 \\
\hline & 1 & 5.77 & 11.20 & 15.33 & 8.44 & 3.79 & 8.91 \\
\hline & 2 & 7.32 & 14.38 & 19.04 & 10.25 & 4.48 & 11.09 \\
\hline \multirow{2}{*}{ Averages } & 1 & 8.21 & 10.91 & 12.32 & 8.41 & 4.68 & \\
\hline & 2 & 10.71 & 14.7 & 15.99 & 9.04 & 5.09 & \\
\hline \multicolumn{8}{|c|}{ The Possibility of an Ecocrisis } \\
\hline \multirow{3}{*}{ 5. Humans are severely abusing the environment } & $\mathrm{S}$ & 31.09 & 25.41 & 20.67 & 11.89 & 10.94 & 2.46 \\
\hline & 1 & 12.92 & 11.89 & 9.82 & 5.17 & 4.74 & 8.91 \\
\hline & 2 & 18.17 & 13.52 & 10.85 & 6.72 & 6.20 & 11.09 \\
\hline \multirow{3}{*}{$\begin{array}{l}\text { 10. The so-called "ecological crisis" facing } \\
\text { humankind has been greatly exaggerated }\end{array}$} & $\mathrm{S}$ & 13.87 & 19.55 & 27.99 & 23.77 & 14.81 & 3.06 \\
\hline & 1 & 6.46 & 9.30 & 11.46 & 11.20 & 6.12 & 8.91 \\
\hline & 2 & 7.41 & 10.25 & 16.54 & 12.58 & 8.70 & 11.09 \\
\hline \multirow{3}{*}{$\begin{array}{l}\text { 15. If things continue on their present course, we } \\
\text { will soon experience a major } \\
\text { ecological catastrophe }\end{array}$} & $\mathrm{S}$ & 31.96 & 20.93 & 22.74 & 12.49 & 11.89 & 2.51 \\
\hline & 1 & 12.66 & 9.56 & 10.42 & 6.46 & 5.43 & 8.91 \\
\hline & 2 & 19.29 & 11.37 & 12.32 & 6.03 & 6.46 & 11.09 \\
\hline \multirow{2}{*}{ Averages } & 1 & 10.68 & 10.25 & 10.57 & 7.61 & 5.43 & \\
\hline & 2 & 14.96 & 11.71 & 13.24 & 8.44 & 7.12 & \\
\hline
\end{tabular}

S, students; 1, ECO school type; 2, regular school type.

Reality element of limits to growth: The respondents felt most strongly about approaching the limit of population on Earth (statement 1$)($ mean $=2.92$; standard deviation $(\mathrm{SD})=1.19$ ), and least strongly about natural resources, which will be more abundant if humans learn to develop them (Statement 6$)$, $($ mean $=2.48 ; \mathrm{SD}=1.30)$.

Anti-anthropocentrism: The students most valued Statement 12 about the dominance of humans over nature (mean $=3.09 ; \mathrm{SD}=1.22)$, and least valued Statement 7 about plants and animals having as much rights as humans (mean $=2.65 ; \mathrm{SD}=1.32$ ).

The fragility of nature's balance: The students rated the strength of nature's balance in coping with the impacts of industry (mean $=3.15 ; \mathrm{SD}=1.26$ ), with the lowest rating being given to Statement 3 , that human interference in natural processes has disastrous consequences $($ mean $=2.63 ; \mathrm{SD}=1.36$ ).

Rejection of exemptionalism: Statement 14 that humans will learn enough about how nature works to be able to manage it (mean $=2.83, \mathrm{SD}=1.12$ ) received the highest score, followed by the statement that despite our abilities, humans are still subject to the laws of nature $($ mean $=2.63, \mathrm{SD}=1.32$ ).

The possibility of an ecocrisis: The students gave the highest rating to "ecological crisis," which they considered to be greatly exaggerated (Statement 10) (mean $=3.06$; $\mathrm{SD}=1.25$ ), while Statement 5 , that humans are severely abusing the environment, receiving the lowest rating (mean $=2.46 ; \mathrm{SD}=1.32$ ).

Particularly characteristic was the attitude toward anti-anthropocentrism, where more than $70 \%$ of the respondents expressed their support for Statement 7 on the rights of plants and animals, as well as the attitude of the students toward the possibility of an ecocrisis, which reveals a concern for the result of human activity in nature as a consequence. However, it should be noted that there was uncertainty (doubt) about the proportions of the various claims that exceed $20 \%$. The most "insecure" statements were the fragility of 
the natural equilibrium $(27.22 \%)$ in Statement 8, the anti-anthropocentrism in Statement 12, and the possibility of an ecocrisis in Statement 10 (23.77\%).

The results showed that students in regular schools are more pro-environmental than those in ECO schools. Particularly characteristic of the ecocrisis option were Statements 5 and 15 , which were supported by more than $30 \%$ of the students, and the rejection of the exemptionalism option (9), which was supported by $30.41 \%$ of the respondents. Less than $30 \%$ of the respondents were in favor of Statements $3(27.98 \%)$ and $13(27.13 \%)$ of the possibility of the fragility of nature's balance. Students in regular schools were also more likely to agree with Statement 7 of the anti-anthropocentrism option $(26.44 \%)$ on the rights of plants and animals compared to the rights of humans. Less common for both regular and ECO school students was the possibility of the reality of limits to growth, with Statement 1 supported by $22.91 \%$ and $14.21 \%$ and Statement 11 supported by $24.80 \%$ and $14.21 \%$ of the respondents in regular and ECO schools, respectively. The students in regular schools were the most "insecure" and felt excluded from the possibility of rejection of exemptionalism for Statement 14 (19.04\%) and from the reality of limits to growth for Statement 1 (18.26\%).

\subsection{Does an Interest in and Practice of Ecology Influence Ecological Attitudes?}

The results of the correlation between the interest and practice of ecology (Table 5) show that the NEP scale is related to the interest and practice of ecology of respondents.

Table 5. Correlation of the NEP statements between those interested in and practicing ecology.

\begin{tabular}{ccc}
\hline NEP Statement & $\begin{array}{c}\text { Identifies as Having an Interest } \\
\text { in Ecology }\end{array}$ & $\begin{array}{c}\text { Identifies as a Practitioner } \\
\text { of Ecology }\end{array}$ \\
\hline 6 & $0.112^{* *}$ & $0.098^{* *}$ \\
\hline 11 & $0.067^{*}$ & \\
\hline \multicolumn{4}{c}{ Anti-anthropocentrism } \\
\hline 7 & $0.137^{* *}$ & $0.134^{* *}$ \\
\hline 3 & The fragility of nature's balance \\
\hline 13 & $0.071^{*}$ & $0.076^{* *}$ \\
\hline & $0.071^{*}$ & $0.060^{*}$ \\
\hline 4 & Rejection of exemptionalism & $0.066^{*}$ \\
\hline 9 & $0.079^{* *}$ & $0.063^{*}$ \\
\hline 14 & $0.072^{*}$ & \\
\hline & $0.106^{* *}$ & $0.071^{*}$ \\
\hline 5 & The possibility of an ecocrisis & $0.090^{* *}$ \\
\hline 15 & $0.130^{* *}$ & $0.109^{* *}$ \\
\hline$*$ Correlation is significant at the 0.01 level (two-tailed); correlation is significant at the 0.05 level (two-tailed).
\end{tabular}

The NEP statements achieved higher correlation coefficients with students studying ecology, who are aware of the possibility of ecocrisis due to the knowledge they acquired at school, as shown in Statements 5 and 15 (0.130 and 0.109). For the respondents with both an interest in and an appreciation of ecology, the seventh statement had circumferential correlation coefficients ( 0.137 and 0.134$)$, indicating that the students are aware of the consequences of human activities in nature. For students who are interested in and practice ecology, a pro-ecological approach is important, as it shows their concern for preserving nature. The weak correlations encourage wider discussion and analysis of the surveys. Moreover, hypothesis $\mathrm{H} 3$ that interest in and practice of ecology influences ecological attitudes was supported. 
Hypothesis $\mathrm{H} 4$ that students in ECO schools are more responsible for the natural environment can be confirmed, as the mean score of 2.8166 for ECO schools was higher than that of regular schools, i.e., 2.7337.

\section{Discussion and Conclusions}

After Lithuania regained its independence, the education system had to be reformed to develop a proper attitude toward nature. Therefore, it was relevant to conduct research with school-aged young people to see to what extent the new generation growing up in independent Lithuania has a developed attitude toward nature, which becomes one of the factors influencing behavior in nature. This study aimed to analyse the influence of values, social environmental factors and interest in and practice of ecology influence the formation of ecological attitudes among students, as measured by the New Ecological Paradigm scale.

Public health education in Lithuanian schools is delivered by public health professionals, with the aim of protecting and improving the health of students in partnership with their parents and the school community. To achieve these goals, the specialist provides the community with information on health protection and health promotion methods and teaches how to put them into practice; organizes and delivers public health education sessions; and helps students develop personal hygiene skills. Schools contribute to improving health by providing appropriate opportunities to educate and address health, mental, and behavioral problems, and Abedi [71] indicated that the culture of society and the culture of the family influences the quality of health and the cooperation of the family with the school to promote the health of their children. Schools play a key role in maintaining the health of children, who bring their health knowledge from the home environment to an environment with health risk factors due to new friends and various games.

For the students, health is the most important personal value, suggesting that health problems may be linked to pollution in the natural environment. From a gender perspective, healthcare is more important for girls than for boys. It should be noted that the respondents completed the questionnaire in the context of COVID-19, which resulted in limitations in social relationships that may have led them to reflect on the importance of health in order to maintain relationships that are not distance-based. The priority given to the value of health also suggests that students are no strangers to the well-being of the environment and society.

The results of this study show a contrasting distribution of values between money as a material value and love as a spiritual value. These findings suggest that the material aspect is more important for students because of the social situation of their family, as many respondents live outside the city, and also because of the social situation of their parents, i.e., whether they work, the level of their income, or whether they have to rely on state support to support their family. Money as a material aspect becomes a form of expression for young persons, and also reveals an attitude toward possessions that are seen through the prism of happiness, which become the center of their lives. Likitapiwat [72] observed that the family environment is important in the development of material values and that parental attitudes toward child-raising and behavior when their needs are not being met become a cause of material values. Parents also use material things to shape the behavior of their children [73]. The impact of self-esteem on material values, which may also depend on how people define themselves, cannot be excluded. Zhang [74] observed that materialism can be a way of fulfilling the goals of affirming human uniqueness and personal qualities.

Unpolluted food, clean air, and fresh water stand out in the context of environmental values among students. Umbrasiene [75] and colleagues pointed out that a healthy diet is the foundation for the health of students, and that parents and the school can lay the foundations for this first. In the not-too-distant past, Lithuanian schools used to have snack vending machines where you could choose from a wide range of sweets and drinks filled with sweeteners, which did not contribute to healthy nutrition among students. These machines were one of the reasons why Lithuanian schoolchildren were overweight, 
exacerbating the problem of obesity. The issues raised by parents and health professionals have led to positive decisions by the state to preserve the health of students, which also influences their quality of life. The eating habits of children are formed in families, and eating habits formed in childhood and established in adolescence determine health and quality of life in adulthood [76]. The results also showed that focusing on healthy food is more important for women. Women are more health-conscious than men when it comes to eating healthy foods. There are gender differences in the perceptions of healthy food that influence eating behavior [77]. Compared to men, women tend to make healthier food choices and are more likely to maintain a healthy diet to keep fit [78]. Among Lithuanian schoolchildren, females are the leading gender in terms of ecological values.

\subsection{Influence of the Social Environment on Ecological Attitudes}

As social beings with their own personality, human beings are influenced by their environment, which is unique in its nature and in the way that it influences human behavior [79]. The cultural environment shapes the person who accepts himself or herself as a member of a particular group and affirms it through their behavior. Mahalakshmi [80] observed that there is a link between personality and the home environment in which personal values are formed. Küçük [81] noted that the behavior of people shows how they are influenced by family, environment, and education. For the students, school becomes an environment characterized by different behaviors than in a smaller family environment, as well as experiences of self-reliance, conflict, and getting along with other students and teachers [81]. For children and adolescents, school is an important part of society, where they spend a lot of time and have new opportunities to interact with their peers and adults. A positive school experience is a healthy ecological environment in which social and emotional development takes place, caring for the quality of life of the community, both individually and collectively. The social, emotional, and academic needs of all students can therefore be adequately addressed by appropriate school policies [82].

For Lithuanian students, school is not the environment in which they can fully develop themselves, and the institution is not crucial for their behavior in nature. This shows that the ongoing reforms in Lithuania are not adequate and have a negative impact on pupils, who should feel comfortable developing themselves as individuals who are responsible not only for themselves but also for their behavior in nature.

The members of a family environment are emotionally connected, in which each family member is accepted unconditionally through love. The family function expresses the ability to protect the family by resolving conflicts, forging alliances between members, achieving discipline, etc. Zakiei [83] noted that in well-functioning families, children are free to express their opinions, to speak their minds on a range of issues, and to make suggestions when necessary. The emotional support of the family helps a person to shape their personality. Jogdan [84] pointed out that parents are the first guides and teachers in the lives of their children, meeting their physical and emotional needs and providing social and psychological support. The presence of parents here and now increases the awareness of a child, preventing them from being subjected to peer group pressure or the influence of the outside world [84]. Parenting styles and parental attitudes have a strong influence on the psychosocial and personality development of adolescents, and the quality of relationships is a determining factor for adjustment and interpersonal communication [85]. In Lithuania, family is more important than school for students in terms of outdoor behavior. This shows that families are talking about nature, the problems caused by climate change and its consequences, and the aspect of responsibility. Students and their families are not indifferent to or unaware of environmental problems, and at the same time, they encourage appropriate personal behavior.

Ajzen [35] highlights that behaviour is controlled by a voluntary decision to do or not to do it, which depends on the availability of suitable opportunities or resources (time, money, skills, cooperation of others, etc.). Outdoor behavior is most influenced by friends, who receive information about nature from school and family. The human and ecological 
values of the students show that they adjust their behavior on the basis of these values, suggesting that both the family and the school are providing appropriate value arguments. Chang [86] noted that every interpersonal relationship is a unique social context, and the complex interplay of circumstances shapes the values, attitudes, behaviors, and beliefs of people. Our research confirms the similarity of the behaviors that adolescents value in friendship. The importance of the experience of friends and close peers as an indicator of life satisfaction is significant, because satisfied individuals tend to have stronger and more intimate social relationships [87]. However, peer groups are often more likely to encourage or endorse risky behavior than families, as adolescents have increasing autonomy in their choice of friends, which depends on the values passed on by parents. For children, parental values determine the rules and boundaries set for behavior and the everyday family atmosphere, which serves as a model for behavior [88].

\subsection{Pro-Environmental Attitudes of Students Based on the NEP Scale}

Despite the prediction made, this scale does not predict behavioral decisions related to ecological issues implicit in its assessment [89]. The knowledge a young person receives in the family environment and deepens through education at school shapes a worldview that will influence their understanding of climate change issues throughout their lives. Kiely [90] observed that students are more supportive of the NEP after the integrated sustainability curriculum, suggesting that the interdisciplinary approach may have influenced the environmental orientation of the students in the desired direction. The school design environment also has an impact on the environmental attitudes of students, i.e., in regular schools and schools designed to improve environmental sustainability. Izadpanahi [91] reported that children who attend sustainably designed schools are more environmentally aware compared to those who attended schools with a traditional design.

Herein, the Lithuanian students agreed with every item on the scale, indicating that they tend to have a pro-environmental attitude. In particular, the majority of the students agreed with the possibility of an ecocrisis and accepted the reality of limits to growth. We think that Lithuanian students, like students in other countries [92], accept such things for the sake of nature. Students in regular general education schools in Lithuania have a more pro-environmental attitude than students who learn in schools that integrate separate elements of ecology and environmental technology education, as well as the values of a healthy lifestyle and of nurturing and creating a healthy environment. In this respect, the results do not call into question the quality of education and the effectiveness of the content of the programs, but as Corraliza pointed out [93], it is not only the knowledge received that is important for the development of environmental awareness, but also the appreciation of the contact with nature, as being in the natural environment enhances environmental attitudes and the intention to be more environmentally responsible. The authors of this research indicate the need to strengthen teaching strategies, to discuss teaching resources and, appropriate support materials, and, of course, to provide teacher training on environmental issues.

This study also sought to discover to what extent the interest of the students themselves contributes to their pro-environmental attitudes. This interest arose from the curiosity of the event or object, which is variable and partially controlled by teachers and is also linked to a positive attitude toward responsibility for the environment. Environmental interest as a personal interest promotes cognitive engagement, and " ... if students are interested in environmental issues, they also have a more positive attitude toward responsibility" (p. 173, [94]). Shared experiences, activities, and a sense of environmental efficacy stimulate interest in environmental problems and motivation to learn more about existing problems, as affective factors are important in developing environmental responsibility [94]. In Lithuania, the respondents are interested in ecology not only at school, but also through informal means such as non-formal education, personal interest, etc. The correlations showed the sensitivity of the students to a possible ecological crisis. 
The results also suggest that students are generally aware of the consequences of human activity in nature.

The authors of this research note that schools have a responsibility to the young people coming from families to develop values and pro-environmental attitudes in their students. For pupils, the value of health is the most important in terms of personal values, which also shows that the health problems of current students encourage them to take care of their own health, and also of the natural environment, which is one of the causes of health problems. Girls are more concerned about their health than boys, which is an indicator of quality of life. The results between the value of money and the value of love encourage a rethinking of the issue of value education, not only in the family, but also at school, where students see teachers as one of the main role models for the development of their values. The prioritization of money also reveals the social problems that students bring from their home environment. In the context of ecological values, the researchers note that healthy food is associated with the health value identified by the students and that this ecological value, along with personal values, is most relevant for girls. The value of healthy food emphasized by girls only confirms that for them it is also linked to staying fit. Lithuanian educational institutions need to look for ways to strengthen their position in the development of attitudes toward values and to have a significant impact on the behavior of pupils in nature, as the results show that friends and family are the most important contributors to the formation of attitudes toward values and the influence on behavior in nature. The NEP scale used by the researchers to measure environmental attitudes showed that Lithuanian students are pro-environmental, but schools that use elements of environmental education and are part of the ECO Schools Network need to look for reasons why their students are less pro-environmental than those in regular schools.

Finally, a limitation of this research is the analysis of the concepts chosen by the researchers according to a specific methodology. For future research, it is relevant to analyze the concept of "value" in relation to ecological awareness, personal development, sustainable development, pro-environmental attitudes, and ecological behavior in order to better understand the values analyzed in context. The results of the study prompt a separate analysis of the extent to which the personal values, social norms, attitudes and perceived behavioural control of pupils are translated into environmentally friendly behaviours, based on the Theory of Planned Behaviour. The results of this research also encourage further research to investigate the role of teachers and parents in the formation of values, ecological attitudes, and ecological awareness of students.

Author Contributions: Conceptualization, R.J. and A.G.; methodology, R.J. and A.Ū.; investigation, R.J. and A.G.; visualization R.J.; writing — original draft preparation and writing-review and editing, R.J., A.G. and A.Ū. All authors have read and agreed to the published version of the manuscript.

Funding: This research received no external funding.

Institutional Review Board Statement: The study was approved at the meeting of the Institute of Applied and Ecology of the Faculty of Forests and Ecology (Minutes number 4, 28 September 2020).

Informed Consent Statement: Informed consent was obtained from all subjects involved in the study.

Data Availability Statement: Study data not provided.

Conflicts of Interest: The authors declare no conflict of interest.

\section{References}

1. Šaulys, A. Historical Development of Environmental Thought and Practice in Soviet Lithuania. Department of History Faculty of Humanities Šiauliai University. 2014. Available online: http:/ /gs.elaba.lt/object/elaba:2172067/2172067.pdf (accessed on 12 July 2021).

2. Lietuvos Respublikos Švietimo İstatymas. 2021. Available online: https:// e-seimas.lrs.lt/portal/legalAct/lt/TAD/TAIS.1480/asr (accessed on 23 July 2021). 
3. Lietuvos Respublikos Švietimo ir Mokslo Ministro. 2008 m Rugpjūčio 26 d. İsakymas Nr. ISAK-2433, 11 Priedas. Available online: https://www.smm.lt/uploads/documents/svietimas/ugdymo-programos/11_Bendruju_kompetenciju__pdf (accessed on 23 July 2021).

4. Niaura, A. Using the Theory of Planned Behavior to Investigate the Determinants of Environmental behavior among Youth. Environ. Res. Eng. Manag. 2013, 1, 74-81. [CrossRef]

5. Panov, V. Ecological Thinking, Consciousness, Responsibility. Procedia-Soc. Behav. Sci. 2013, 86, 379-383. [CrossRef]

6. Infield, M.; Entwistle, A.; Anthem, H.; Mugisha, A.; Phillips, K. Reflections on cultural values approaches to conservation: Lessons from 20 years of implementation. Oryx 2017, 52, 220-230. [CrossRef]

7. Targamadzè, V. Vertybès sampratos turinio erdvè ir jos reikšmè asmens gyvenime ir valstybès politikoje. Logos 2017, 90, 99-106. [CrossRef]

8. Kuzmickas, B. Vertybès Kultūrų Kontekstuose; UAB Vitae Litera: Vilnius, Lithuania, 2013; p. 19, ISBN 978-9955-19-540-5.

9. Seewann, L.; Verwiebe, R. How do people interpret the value concept? Development and evaluation of the value conceptualisation scale using a mixed method approach. J. Beliefs Values 2020, 41, 419-432. [CrossRef]

10. Shams, L.; Sari, A.A.; Yazdani, S. Values in Health Policy-A Concept Analysis. Int. J. Health Policy Manag. 2016, 5, 623-630. [CrossRef] [PubMed]

11. Kheirandish, S.; Funk, M.; Wensveen, S.; Verkerk, M.; Rauterberg, M. A comprehensive value framework for design. Technol. Soc. 2020, 62, 101302. [CrossRef]

12. Huguelet, P.; Guillaume, S.; Vidal, S.; Mohr, S.; Courtet, P.; Villain, L.; Girod, C.; Hasler, R.; Prada, P.; Olié, E.; et al. Values as determinant of meaning among patients with psychiatric disorders in the perspective of recovery. Sci. Rep. 2016, 6, 27617. [CrossRef] [PubMed]

13. Jones, N.; Shaw, S.; Ross, H.; Witt, K.; Pinner, B. The study of human values in understanding and managing social-ecological systems. Ecol. Soc. 2016, 21, 3413-3422. [CrossRef]

14. Liobikiene, G.; Juknys, R. The role of values, environmental risk perception, awareness of consequences, and willingness to assume responsibility for environmentally-friendly behaviour: The Lithuanian case. J. Clean. Prod. 2016, 112, 3413-3422. [CrossRef]

15. Martišauskienė, E.; Vaičekauskienè, S. Vertybès bendrojo ugdymo mokykloje: Pedagogu požiūris. Pedagogika 2015, 2, 127-144. [CrossRef]

16. Minelgaitè, A.; Liobikienè, G. Changes in pro-environmental behaviour and its determinants during long-term period in a transition country as Lithuania. Environ. Dev. Sustain. 2021, 2, 1-17. [CrossRef]

17. Jančius, R.; Gavenauskas, A.; Pekarskas, J. Visuomenès ekologinis švietimas darnios plètros kontekste. Reg. Form. Dev. Stud. 2021, 25, 46-54. [CrossRef]

18. Kociszewska, M. Ecological awareness and education of the society in the light of sustainability idea-Selected aspects. Pedag. Rodz. 2014, 4, 31-41. [CrossRef]

19. Bai, Y.; Fu, L.; Zhang, Y.; Xiong, X. Pro-Environmental Awareness and Behaviors on Campus: Evidence from Tianjin, China. Eurasia J. Math. Sci. Technol. Educ. 2017, 14, 427-445. [CrossRef]

20. Omoogun, A.C.; Egbonyi, E.E.; Onnoghen, U.N. From Environmental Awareness to Environmental Responsibility: Towards a Stewardship Curriculum. J. Educ. Issues 2016, 2, 60-72. [CrossRef]

21. Cynk, K. The State of the Environmental Awareness of Students from Poland, Slovakia and Ukraine-Selected Results. Civ. Environ. Eng. Rep. 2017, 24, 21-37. [CrossRef]

22. Arifin, R.; Binti, M.; Wahab, N.B.A.; Teh, K.S.; Bin, M.; Otman, M.S. Influence of Social Environment on Student's Behaviour. Int. J. Acad. Res. Bus. Soc. Sci. 2018, 8, 930-939. [CrossRef]

23. Manju, N.D. Social maturity of B. Ed student teachers. Int. J. Innov. Res. Educ. Sci. 2016, 3, $24-28$.

24. Kovacs, A. The Role of Social Environment in the Formation of Adult English Language Learners' Attitudes to Learning English: A Pilot Study. WoPaLP 2011, 5, 100-117.

25. Thomas, G.O.; Fisher, R.; Whitmarsh, L.; Milfont, T.L.; Poortinga, W. The impact of parenthood on environmental attitudes and behaviour: A longitudinal investigation of the legacy hypothesis. Popul. Environ. 2018, 39, 261-276. [CrossRef]

26. Langa, C.; Langa, C. The impact of social environment on scholar activities of primary school's pupils. Eur. Proc. Soc. Behav. Sci. 2017, 1-14. [CrossRef]

27. Anand, A.K.; Kunwar, N.; Kumar, A. Impact of different Factors on Social Maturity of Adolescents of Coed-School. Int. Res. J. Soc. Sci. 2014, 3, 35-37.

28. Stewart, K. Examining Student and Teacher Perceptions of the Classroom Social Environment across School Context: Effects of Individual Factors. Ph.D. Thesis, Psychological and Social Foundations, University of South Florida, Tampa, FL, USA, 2016. Available online: http:/ / scholarcommons.usf.edu/etd/6400 (accessed on 10 May 2021).

29. Moreira, P.; Pedras, S.; Pombo, P. Students' Personality Contributes More to Academic Performance than Well-Being and Learning Approach-Implications for Sustainable Development and Education. Eur. J. Investig. Health Psychol. Educ. 2020, 10, 1132-1149. [CrossRef] [PubMed]

30. Garibaldi, M.; Josias, L. Designing schools to Support Socialization Processes of Students. Procedia Manuf. 2015, 3, 1587-1594. [CrossRef]

31. Karakaya, F.; Yilmaz, M. Environmental ethics awareness of teachers. Int. Electron. J. Environ. Educ. 2017, 7, 105-115. 
32. Hebel, F.L.; Montpied, P. What can influence students' environmental attitudes? Results from a study of 15-year-old students in France. Int. J. Environ. Sci. Educ. 2014, 9, 329-345. [CrossRef]

33. Tarfaoui, D.; Zkim, S. Ecological attitude-Behavior gap: A theoretical analysis. Int. J. Econ. Strateg. Manag. Bus. Process 2017, 8, 33-38.

34. Marcinkowski, T.; Reid, A. Reviews of research on the attitude-behavior relationship and their implications for future environmental education research. Environ. Educ. Res. 2019, 25, 459-471. [CrossRef]

35. Ajzen, I. The Theory of Planned Behavior: Frequently Asked Questions. Hum. Behav. Emerg. Tech. 2020, 2, 314-324. [CrossRef]

36. De Leeuw, A.; Valois, P.; Ajzen, I.; Schmidt, P. Using the theory of planned behavior to identify key beliefs underlying proenvironmental behavior in high-school students: Implications for educational interventions. J. Environ. Psychol. 2015, 42, 128-138. [CrossRef]

37. Varah, F.; Mahongnao, M.; Francis, D.J.; Shimrah, T. Measuring environmental attitudes and behaviors: A study of undergraduate students in Delhi. Nat. Hazards 2020, 103, 1291-1306. [CrossRef]

38. Yapici, G.; Ögenler, O.; Kurt, A.Ö.; Şaşmaz, F.K.T. Assessment of environmental attitudes and risk perceptions among university students in Mersin, Turkey. J. Environ. Public Health 2017, 2017, 5650926. [CrossRef]

39. Gustria, A.; Fauzi, A. Analysis of high school students' environmental attitude. J. Phys. Conf. Ser. 2019, 1185, 1-5. [CrossRef]

40. Lucarelli, C.; Mazzoli, C.; Severini, S. Applying the Theory of Planned Behavior to Examine Pro-Environmental Behavior: The Moderating Effect of COVID-19 Beliefs. Sustainability 2020, 12, 10556. [CrossRef]

41. Syahri, M. Developing students' environmental attitude through malang waste bank program. Adv. Soc. Sci. Educ. Humanit. Res. 2019, 349, 297-300.

42. La Fua, J.; Wekke, I.; Sabara, Z.; Nurlila, R. Development of Environmental Care Attitude of Students through Religion Education Approach in Indonesia. IOP Conf. Ser. Earth Environ. Sci. 2018, 175, 012229. [CrossRef]

43. Omran, M.S. The effect of educating environmental ethics on behavior and attitude to environment protection. Eur. Online J. Nat. Soc. Sci. 2014, 3, 141-150.

44. Sarıçam, H.; Şahin, S.H. The Relationship between the Environmental Awareness, Environmental Attitude, Curiosity and Exploration in Highly Gifted Students: Structural Equation Modelling. Educ. Process. Int. J. 2015, 4, 7-17. [CrossRef]

45. Jena, L.K.; Behera, B. Pork consumer preferences in Swaziland. Int. J. Dev. Sustain. 2017, 6, 561-574.

46. Lamanauskas, V.; Augienienè, D. Primary school fourth grade students' ecological attitude diagnostics. In Proceedings of the 3rd International Baltic Symposium on Science and Technology Education, BalticSTE 2019, Šiauliaim, Lithuania, 17-20 June 2019; pp. 114-118, ISBN 978-609-95513-5-7.

47. Atstaja, D.; Susniene, R.; Jarvis, M. The role of economics in education for sustainable development; the baltic states' experience. Int. J. Econ. Sci. 2017, 6, 1-29. [CrossRef]

48. Agirreazkuenaga, L. Education for Agenda 2030: What Direction do We Want to Take Going Forward? Sustainability 2020, 12, 2035. [CrossRef]

49. Agbedahin, A.V. Sustainable development, Education for Sustainable Development, and the 2030 Agenda for Sustainable Development: Emergence, efficacy, eminence, and future. Sustain. Dev. 2019, 27, 669-680. [CrossRef]

50. Boca, G.D.; Saraçl1, S. Environmental Education and Student's Perception, for Sustainability. Sustainability 2019, 11, 1553. [CrossRef]

51. Ardoin, N.M.; Bowers, A.W.; Gaillard, E. Environmental education outcomes for conservation: A systematic review. Biol. Conserv. 2020, 241, 108224. [CrossRef]

52. Collado, S.; Rosa, C.; Corraliza, J. The Effect of a Nature-Based Environmental Education Program on Children's Environmental Attitudes and Behaviors: A Randomized Experiment with Primary Schools. Sustainability 2020, 12, 6817. [CrossRef]

53. Thor, D.; Karlsudd, P. Teaching and Fostering an Active Environmental Awareness Design, Validation and Planning for ActionOriented Environmental Education. Sustainability 2020, 12, 3209. [CrossRef]

54. Karataş, A. The Role of Faculties of Education in Increasing Sustainable Environmental Awareness of Society. Eur. J. Sustain. Dev. 2013, 2, 233. [CrossRef]

55. Mohamad, M.M.; Ibrahim, B.; Lai, C.S.; Ahmad, A.; Md Nasir, A.N. Reflection on environmental awareness for school management. J. Crit. Rev. 2020, 6, 265-268.

56. Erkal, S.; Gürsoy, N. Importance of environmental education to achievement of sustainable development. AWER Procedia Adv. Appl. Sci. 2013, 1, 1042-1045.

57. Sola, A.O. Environmental Education and Public Awareness. J. Educ. Soc. Res. 2014, 4, 333. [CrossRef]

58. Dytrtova, R.; Nemejc, K. Evaluation of awareness and implementation of environmental education in teachers of secondary vocational schools. Rural. Environ. Educ. Personal. 2018, 11, 66-73. [CrossRef]

59. Ponmozhi, D.; Krishnakumari, S. Environmental attitude of school students. IOSR J. Humanit. Soc. Sci. 2017, 22, 1-4. [CrossRef]

60. Lietuvos Respublikos švietimo ir mokslo ministras. Dél ekologijos ir aplinkos technologiju ugdymo sampratos tvirtinimo, V-379; 2015. Available online: https:/ / www.smm.lt/uploads/documents/Pedagogams/Ekologijos\%20ir\%20aplinkos\%20technologij\%C5 \%B3\%20\%20ugdymo\%20samprata.pdf (accessed on 23 July 2021).

61. Wadkar, S.K.; Singh, K.; Chakravarty, R.; Argade, S.D. Assessing the Reliability of Attitude Scale by Cronbach's Alpha. J. Glob. Commun. 2016, 9, 113. [CrossRef]

62. Kalenda, Č. Ekologinè problema: Turinys, esmè, ištakos. Problemos 2014, 58, 42-54. [CrossRef] 
63. Dunlap, R.; Van Liere, K.D.; Mertig, A.G.; Jones, R.E. Measuring endorsement of the New Ecological Paradigm: A revised NEP scale. J. Soc. Issues 2000, 56, 425-442. [CrossRef]

64. Putrawan, I.M.; Ananda, R. A Mediated Role of Students New Environmental Paradigm (NEP) between Environmental Personality and Pro-Eco Behavior. Indian J. Public Health Res. Dev. 2019, 10, 1290. [CrossRef]

65. Yuan, T.; Bo, X. The implications of SCAP students' personal values and New Ecological Paradigm view on green behaviour: A perspective of ecological man in simplified norm activation model. Earth Environ. Sci. 2020, 576, 012033. [CrossRef]

66. Ntanos, S.; Kyriakopoulos, G.; Skordoulis, M.; Chalikias, M.; Arabatzis, G. An Application of the New Environmental Paradigm (NEP) Scale in a Greek Context. Energies 2019, 12, 239. [CrossRef]

67. Emmert-Streib, F.; Dehmer, M. Understanding Statistical Hypothesis Testing: The Logic of Statistical Inference. Mach. Learn. Knowl. Extr. 2019, 1, 945-961. [CrossRef]

68. Pandey, R.M. Commonly used t-tests in medical research. J. Pract. Cardiovasc. Sci. 2015, 1, 185-188. [CrossRef]

69. Taber, K.S. The Use of Cronbach's Alpha When Developing and Reporting Research Instruments in Science Education. Res. Sci. Educ. 2018, 48, 1273-1296. [CrossRef]

70. Da Silva, J.V.; Baptista, M.N. Vitor Quality of Life Scale for the Elderly: Evidence of validity and reliability. SpringerPlus 2016, 5, 1450. [CrossRef]

71. Abedi, H.; Abbaszadeh, A.; Motaghi, M. Factors Influencing school health in elementary schools in Isfahan, Iran: A qualitative study. IJCBNM 2016, 4, 352-362.

72. Likitapiwat, T.; Sereetrakul, W.; Wichadee, S. Examining materialistic values of university students in Thailand. Int. J. Psychol. Res. 2015, 8, 109-118. [CrossRef]

73. Richins, M.L.; Chaplin, L.N. Material Parenting: How the Use of Goods in Parenting Fosters Materialism in the Next Generation. J. Consum. Res. 2015, 41, 1333-1357. [CrossRef]

74. Zhang, Y.; Hawk, S.T. Considering the Self in the Link Between Self-Esteem and Materialistic Values: The Moderating Role of Self-Construal. Front. Psychol. 2019, 10, 1375. [CrossRef] [PubMed]

75. Umbrasienè, N.; Varvuolienè, R.; Krupskienè, A.; Narkauskaitè, L.; Beržanskytè, A.; Kranauskas, A. Mokiniu mytybos ipročiai. Visuomenés Sveik. 2011, 2, 76-82. Available online: https://www.hi.lt/lt/visuomenes-sveikata-2011-nr-2-53.html (accessed on 26 July 2021).

76. Strukčinskienė, B.; Strazdienè, N.; Griškonis, S. PRADINIŲ klasių mokiniu mitybos namuose ir mokykloje ypatumai. Visuomenès Sveik. 2015, 4, 5-9. [CrossRef]

77. Bärebring, L.; Palmqvist, M.; Winkvist, A.; Augustin, H. Gender differences in perceived food healthiness and food avoidance in a Swedish population-based survey: A cross sectional study. Nutr. J. 2020, 19, 1-8. [CrossRef]

78. Alkazemi, D.U. Gender differences in weight status, dietary habits, and health attitudes among college students in Kuwait: A cross-sectional study. Nutr. Health 2018, 25, 75-84. [CrossRef] [PubMed]

79. Siramkaya, S.B.; Aydın, D.; Siramkaya, S.B. "Social Space" Concept in the Psycho-Social Development of University Youth and its Exemplification in Faculty Buildings *. Procedia-Soc. Behav. Sci. 2014, 140, 246-254. [CrossRef]

80. Mahalakshmi, D.; Kalaivani, C.; Pugalenthi, N. PERSONALITY and home environment among the higher secondary school students. Shanlax Int. J. Educ. 2015, 4, 40-47.

81. Küçük, S.; Habaci, M.; Göktürk, T.; Ürker, A.; Adiguzelli, F. Role of family, environment and educat on on the personal ty development. Middle-East J. Sci. Res. 2012, 12, 1078-1084. [CrossRef]

82. López, V.; Torres-Vallejos, J.; Ascorra, P.; González, L.; Ortiz, S.; Bilbao, M. Contributions of Individual, Family, and School Characteristics to Chilean Students' Social Well-Being at School. Front. Psychol. 2021, 12, 620895. [CrossRef]

83. Zakiei, A.; Vafapoor, H.; Alikhani, M.; Farnia, V.; Radmehr, F. The relationship between family function and personality traits with general self-efficacy (parallel samples studies). BMC Psychol. 2020, 8, 1-11. [CrossRef]

84. Jogdand, S.S.; Naik, J. Study of family factors in association with behavior problems amongst children of 6-18 years age group. Int. J. Appl. Basic Med. Res. 2014, 4, 86-89. [CrossRef]

85. Arulsubila, M.; Subasree, R. Parenting styles influencing personality development of catering students. Int. J. Indian Psychol. 2016, 4, 181-188. [CrossRef]

86. Chang, C.-Y. The effects of friendship and antipathy networks on adolescent attitude similarity. Int. J. Adolesc. Youth 2015, 20, 407-428. [CrossRef]

87. Amati, V.; Meggiolaro, S.; Rivellini, G.; Zaccarin, S. Social relations and life satisfaction: The role of friends. Genus 2018, 74, 7. [CrossRef]

88. Álvarez-García, D.; González-Castro, P.; Núñez, J.C.; Rodríguez, C.; Cerezo, R. Impact of Family and Friends on Antisocial Adolescent Behavior: The Mediating Role of Impulsivity and Empathy. Front. Psychol. 2019, 10, 2071. [CrossRef]

89. Derdowski, L.; Grahn, Å.; Hansen, H.; Skeiseid, H. The New Ecological Paradigm, Pro-Environmental Behaviour, and the Moderating Effects of Locus of Control and Self-Construal. Sustainability 2020, 12, 7728. [CrossRef]

90. Kiely, L.; Parajuly, K.; Green, J.A.; Fitzpatrick, C. Education for UN Sustainable Development Goal 12: A Cross-Curricular Program for Secondary Level Students. Front. Sustain. Food Syst. 2021, 2, 638294. [CrossRef]

91. Izadpanahi, P.; Tucker, R. NEP (Children@School): An Instrument for Measuring Environmental Attitudes in Middle Childhood. Aust. J. Environ. Educ. 2018, 34, 61-79. [CrossRef] 
92. Atav, E.; Altunoğlu, B.D.; Sönmez, S. The Determination of the Environmental Attitudes of Secondary Education Students. Procedia-Soc. Behav. Sci. 2015, 174, 1391-1396. [CrossRef]

93. Corraliza, J.A.; Collado, S. Ecological awareness and children's environmental experience. Pap. Psicól. Psychol. Pap. 2019, 40, 190-196. [CrossRef]

94. Uitto, A.; Juuti, K.; Lavonen, J.; Byman, R.; Meisalo, V. Secondary school students' interests, attitudes and values concerning school science related to environmental issues in Finland. Environ. Educ. Res. 2011, 17, 167-186. [CrossRef] 